\title{
Reduction of Anxiety Levels in Schizophrenia Patients Using Progressive Muscle Relaxation
}

\section{Yanah kuscianah Kuswa1}

1 Eredah Complex Mental Health Hospital, Najran, Saudi Arabia.

\section{Article Info}

Article History:
Submitted: May 26th
Accepted: June 14th
Published: June 23rd
Keywords:
Progressive muscle
relaxation; Anxiety;
Schizophrenia

\begin{abstract}
Anxiety neurosis is the most common mental disorder in society. Progressive muscle relaxation is an independent nursing intervention that can be chosen to reduce anxiety in schizophrenia patients. This case study aims to prove that progressive muscle relaxation can help reduce anxiety levels in schizophrenic patients. The study design is descriptive in the form of a case study with a nursing process approach, applying progressive muscle relaxation techniques to schizophrenic patients who experience problems with anxiety levels. The sample was two adult schizophrenic patients who experienced anxiety in Eredah Complex Mental Health Hospital. The patient's anxiety was measured by the Zung-Self Anxiety Rating Scale. The progressive muscle relaxation procedure is performed 2 times over two days with a duration of 20-30 minutes each session. Hemodynamic measurements and anxiety levels were performed pre-post progressive muscle relaxation. The results of the case study showed that progressive muscle relaxation interventions affected reducing patient anxiety levels. The mean score of the patient's anxiety decreased by $30.34 \%$ after being given progressive muscle relaxation. Progressive muscle relaxation is effectively applied to schizophrenic patients with anxiety disorders in nursing service settings.
\end{abstract}

\section{INTRODUCTION}

Schizophrenia is a functional psychosis with major disorders of the thought process as well as disharmony between thought processes, affections or emotions, willpower and psychomotor accompanied by distortions of reality mainly due to delusions and hallucinations, dissociation so that incoherence, affective and emotional imbalance arise, psychomotor shows withdrawal, ambivalence and bizarre behavior. ${ }^{1}$ Schizophrenic patients experience impaired current formation as well as the content of the mind. In addition, there are also disturbances of perception, self-insight, feelings and desires. In schizophrenia it is found that 7 per 1000 adults, aged mostly between $15-35$ years' patients experienced disinterest, isolation, unruly and anxious behavior. ${ }^{2}$

Anxiety is an emotional response to judgment that describes a state of worry, anxiety, fear of insecurity accompanied by various physical complaints. These circumstances can occur in a variety of life situations besides illness disorders. in

Corresponding author:

Yanah kuscianah kuswa

ykuswa@moh.gov.sa

South East Asia Nursing Research, Vol 3 No 2, June 2021

ISSN:2685-032X

DOI: https://doi.org/10.26714/seanr.3.2.2021.90-97 
addition, anxiety can cause a reaction that will occurs in a repeated manner, such as emptiness in the stomach, shortness of breath, heart palpitations, sweating profoundly, headaches, desire to urinate and defecate, this feeling is accompanied by a feeling of wanting to move to run away from things that are worried. Anxiety if kept untreated it can affect both physical and psychological conditions. $^{3}$ A WHO 2019 report shows that depression and anxiety can cause global economic losses of 1 trillion $\$$ annually due to loss of human resource productivity. 4

The most psychotic mental disorders are schizophrenia. Such disorders can be in the form of speech and disorganized behavior, flat affect, excessive motor activity, uncontrollable movements, there is also anger, keeping isolated and even resulting in anxiety. If the anxiety is not resolved immediately, then the schizophrenic client will experience a deterioration of his life function including the healing process will be hamper. ${ }^{3}$ The most psychotic mental disorders are schizophrenia. Such disorders can be in the form of speech and disorganized behavior, flat affect, excessive motor activity, uncontrollable movements, there is also anger, keeping isolated and even resulting in anxiety. If the anxiety is not resolved immediately, then the schizophrenic client will experience a deterioration of his life function including the healing process will be hampered. ${ }^{5}$

A person who is experiencing anxiety, tends to experience changes in perception and has negative thoughts related to the problems they face. If a person is always negativeminded then there are several impacts including: decreased health status, decreased function of one's adaptation to environmental changes, pessimistic attitude towards the future and tendency to depression and decreased quality of life. Therefore, an intervention is needed that can break the cycle of negative thoughts experienced by individuals experiencing anxiety $^{6}$ and progressive muscle relaxation. ${ }^{7}$ Previous research suggests progressive muscle relaxation effectively that can have reduced anxiety in schizophrenic patients because progressive relaxation exercises are one of the proven muscle relaxation techniques in therapy programs against muscle tension abled to overcome complaints of anxiety, insomnia, fatigue, muscle cramps, neck and waist pain, high blood pressure, mild phobia and stuttering. Progressive relaxation techniques can be used for the execution of psychic problems. Relaxation produced by progressive muscle relaxation techniques can be beneficial for lowering anxiety. ${ }^{7}$

This case study relates to a progressive muscle relaxation technique which is one of the behavioral therapies used for schizophrenic patients experiencing anxiety. Progressive relaxation is one of the nursing interventions that can be used as an action to improve comfort, relaxation that can affect physiological and psychological responses. This intervention was chosen because it is easy to do, can be used in a variety of situations, easy to learn, cheap and safe. Relaxation is one form of mind body therapy in complementary therapy (Complementary and Alternative Therapy). Relaxation has the effect of a calming sensation of the limbs, lightness, and feeling warmth that spreads throughout the body. Changes that occur during and after relaxation affect the work of the autonomic nervous system. The emotional response and calming effects posed by this relaxation turn the dominant physiology of the sympathetic into the dominant parasympathetic system. ${ }^{8}$ Catecholamine and cortisol hypersecretion in anxious state is lowered and increases parasympathetic hormones as well as neurotransmitters such as Dehydroepinandrosterone (DHEA) and dopamine or endorphins. The regulation of this parasympathetic system eventually caused a calming effect. ${ }^{9}$ The purpose of this case study is to help lower the anxiety levels of schizophrenic patients with progressive muscle relaxation therapy. 


\section{METHODS}

This case study uses descriptive design with a nursing care process approach. The subject of this case study was a schizophrenic patient who was hospitalized at Saudi Arabia's Eradah Complex for Mental Health (ERMHN). The study subjects were two schizophrenia patients who experienced anxiety who were random selected. The inclusion criteria of study subjects were female, mature age and able to communicate verbally. This case study was conducted on December 2020.

Regarding the selected case, the problem is anxious nursing care in schizophrenic clients with a study focus on the effect of progressive relaxation on patient anxiety levels. Data collection is conducted by interviewing patients, the patient's family and from the patient's medical record. Observation of anxiety levels is done by paying attention to the signs and symptoms of anxiety that appear, measured by the questionnaire Zung-Self Rating Anxiety, Scale as a gauge of anxiety levels that have been tested validity and reliability. ${ }^{10}$

Progressive muscle relaxation procedure, each session starts from recommending the subject to wear comfortable and not narrow clothes. The next procedure performs relaxation of the jaw muscles, recommends stretching the muscles for 5 to 10 seconds, relaxing the muscles 20-30 seconds, 8 to 16 times each, followed by stretching the leg muscles for no more than 5 seconds to avoid cramping. During the procedure the nurse recommends focusing on the stretched muscles, focusing on relaxing muscle sensations and recommending a slow deep breath. The procedure is carried out 2 times over two days with a duration of 20-30 minutes each session, carried out in a quiet place. Both patients continued to take the drug according to their pharmacological therapy program. Progressive muscle relaxation procedure is carried out 10-15 minutes after taking antidepressant drugs. The focus of interventions to lower anxiety levels, respondents helped create a therapeutic state to induce trust, assist patients to reduce their anxiety and listen attentively to all complaints. Both patients are also advised to conduct their outside the meeting session.

This study applies research ethics. Case study subjects are given the freedom to be the subject of a case study after being given an understanding of the purpose and benefits of progressive muscle relaxation therapy. Case study subjects are required to sign an approval sheet prepared by the researcher and the name of the case study subject is not displayed in the publication text. The management of the obtained case study data was presented and analyzed to determine the decrease in anxiety score after progressive muscle relaxation. The data of patient anxiety are presented in the form of tables.

\section{RESULTS}

Two of subject studies were muslim, female with the age between 30-40 years. Both subjects of the case study found anxiety was evidenced by complaints of insomnia, irritability, feeling sad, feeling confused and worried. Objectively it looks tense and restless. Measurement of the anxiety levels of both subjects using the Zung-Self Rating Anxiety Scale. The results of the second anxious level measurement of the study subjects were a score of 45 for case 1 subjects and a score of 44 on case 2 subjects. Both study subjects belonged to the moderate anxiety level category. Both case study subjects obtained antidepressant medications. The subject of the first case study got therapy Benzodiazepam (tablets Clonazepam $2 \mathrm{mg}$ hours of sleep and tablets Escitalopram 10mg once daily). Subject of two case studies given antidepressant therapy (tablets Escitalopram $20 \mathrm{mg}$ once dalily and Mirtazapin 30mg hours of sleep). 
The primary nursing diagnosis of both patients is anxiety related to crisis situation. ${ }^{11}$ The diagnosis of nursing is characterized by the appearance of symptoms of subjective major signs that the patient feels confused and worried and physically appears tense, restless and has difficulty sleeping. Other data supporting anxiety are an anxiety score with a score of 45 for case subject 1 and a score of 44 on case subject 2 .

The nursing intervention in the case study subjects was anxiety reduction with progressive relaxation therapy. ${ }^{12}$ The nursing plan of both subjects is after progressive muscle relaxation intervention for 48 hours, anxiety rate decreases. The criteria for this external result is decreased verbalization of confusion, verbalization is concerned due to the condition faced decreases, decreased restless behavior, decreased tense behavior complaints of dizziness, anorexia, palpitations, diaphoresis, tremor and pale absence, vital signs within normal limits. ${ }^{13}$

Planning for the management of anxiety reduction with progressive muscle relaxation techniques in accordance with the principles of intervention, namely observation, therapeutic education and collaboration. Observational nursing interventions include: identification when the level of anxiety changes, identification of decision-making ability, monitoring of verbal and nonverbal anxiety signs, identification of calm and comfortable places, regular monitors to ensure muscles relaxation and monitor the presence of indicators are not relaxed. Therapeutic plans include: set the environment so that there are no interruptions during therapy, give the position leaning on the chair or other comfortable positions, stop the therapy session gradually and give time to express feelings

about therapy. The educational plan consists of: recommend wearing comfortable and not narrow clothes, recommending progressive muscle relaxation according to the procedure). The collaboration plan is the administration of anti-anxiety drugs if necessary. ${ }^{12}$

The progressive relaxation procedure in this study was carried out in a seated position. In performing progressive relaxation techniques, perform the procedures described as well as repeat each instruction. Respondents are recommended to stretch each muscle group for 5-7 seconds then relax for 20-30 seconds, then follow the next steps according to the progressive muscle relaxation therapy procedure. An overview of the evaluation of anxiety scores and vital signs before and after progressive muscle relaxation in both case study subjects can be seen in table 1 .

Table 1 shows changes in anxiety levels after two days of intervention followed by changes in vital signs. The anxiety scores of both study subjects decreased by more than $40 \%$ after being given progressive muscle relaxation. The physiological response of both respondents was quite good after progressive muscle relaxation intervention. Patients are more relaxed after being given progressive muscle relaxation as evidenced by a decrease in blood pressure, pulse and respiratory rate. Both respondents were quite cooperative during progressive muscle relaxation techniques.

Evaluation of nursing care is done after 48 hours. After progressive muscle relaxation interventions were performed on both respondents, there was a decrease in anxiety levels from the moderate category to the mild category followed by changes in vital signs within normal limits. Both respondents said they felt calm, relaxed and their worries diminished. 
Table 1

Pre-Post Observation Parameters of Progressive Muscle Relaxation Therapy on Scizofrenia

\begin{tabular}{lcccccccc}
\hline $\begin{array}{l}\text { Measurement } \\
\text { Indicators }\end{array}$ & \multicolumn{4}{c}{ Subject Study 1 } & \multicolumn{3}{c}{ Subject Study 2 } \\
\cline { 2 - 9 } & $\begin{array}{c}\text { Anxiet } \\
\text { y Score }\end{array}$ & $\begin{array}{c}\text { BP } \\
(\mathrm{mmHg})\end{array}$ & $\begin{array}{c}\text { Pulse } \\
(\mathrm{x} / \mathrm{min})\end{array}$ & $\begin{array}{c}\mathrm{RR} \\
(\mathrm{x} / \mathrm{min})\end{array}$ & $\begin{array}{c}\text { Anxiet } \\
\text { y Score }\end{array}$ & $\begin{array}{c}\text { BP } \\
(\mathrm{mmHg})\end{array}$ & $\begin{array}{c}\text { Pulse } \\
(\mathrm{x} / \mathrm{min})\end{array}$ & $\begin{array}{c}\text { RR } \\
(\mathrm{x} / \mathrm{min})\end{array}$ \\
\hline $\begin{array}{l}\text { Pre-Intervention } \\
\begin{array}{l}\text { Post-Intervention } \\
\% \text { Decrease score }\end{array}\end{array}$ & 45 & $120 / 80$ & 86 & 20 & 44 & $130 / 80$ & 88 & 20 \\
\begin{tabular}{l} 
after intervention \\
\hline
\end{tabular} & $40,6 \%$ & $118 / 80$ & 76 & 18 & 30 & $120 / 70$ & 80 & 18 \\
\hline
\end{tabular}

\section{DISCUSSION}

Both of subjects were female. But some of the results of the study states that the gender of the women are prone to the onset of anxiety. A study at Lampung Hospital also found that there is a sex relationship with anxiety levels. Gender factors can significantly affect a patient's anxiety levels, in the study it was also mentioned that female gender is more at risk of anxiety compared to male gender. ${ }^{14}$ Gender differences in DSM-IV anxiety disorders were examined in a large sample of adults $(N=20,013)$ in the United States Women showed that women have consistently higher prevalence rates of anxiety disorders. ${ }^{15}$

The average age of both study subjects was between 30-40 years. Maturity or maturity of an individual can affect the coping ability of a person's mechanism so that individuals who are more likely to experience anxiety because the individual has a greater adaptability to anxiety than the age that has not mature. Proven in the study obtained a mature age that is more prevalence of anxiety levels less compared to adolescence. This proves that mature age has sufficient coping ability in overcoming anxiety. ${ }^{14}$

Anxiety that arises in both study subjects due to the occurrence of natural emotional disorders that arise by characterized by deep and sustained fear, so that there can be a disorder in assessing reality, full personality, behavior can be disturbed but still within normal limits, that this indicates they experience anxiety. Schizophrenic patients experience anxiety where the symptoms of anxiety themselves are both severe and moderate are psychiatric disorders. The causes of anxiety arise because of fear of not accepting in certain environments, traumatic experiences, such as separation trauma, loss or natural disasters, and the frustration of failure when meeting their needs. ${ }^{3}$

The results of this study prove that progressive muscle relaxation therapy can reduce muscle tension, anxiety, fatigue, anxiety control so that it can affect the mental status of clients especially in schizophrenia patients. Concentration of attention to tense muscles then lowers tension by performing relaxation techniques, to get a feeling of relaxation, provide comfort to the patient so as to affect the mental status of the patient. The feeling of relaxation will be directed to the hypothalamus to produce Corticotrophin Releasing Hormone (CRH) and Corticotrophin Releasing Hormone (CRH) activating the anterior pituitary to secrete encephalin and endorphins that act as neurotransmitters that affect mood to be relaxed. In addition, anterior pituitary secretion of Adrenocorticotropic hormone (ACTH) decreases, then Adrenocorticotropic hormone (ACTH) controls the adrenal cortex to control cortisol secretion. Decreased levels of ACTH and cortisol cause stress and tension to decrease which can eventually lower depression levels. ${ }^{16}$ The results of this case study also match previous research that progressive muscle relaxation therapy has beneficial effects in reducing anxiety, depression, improved feelings of self-control, and also improving the ability to cope with stress in a variety of situations. ${ }^{17}$ 
The results of this study are also in line with research on the influence of relaxation techniques on changes in the mental status of schizophrenic clients in Surakarta Mental Hospital. This research is an experiment with the design of pre and post test with control group research. The conclusion of the study was that in the treatment group that obtained relaxation techniques there were significant changes to the assessment of mental status. In the control group that did not get relaxation techniques there were no significant changes to the assessment of mental status. The difference that occurs after being given relaxation techniques in the treatment group is very good and has a very significant effect with p-value is 0.001 $(\mathrm{p}<0.05)$. While in the control group there is no significant influence. ${ }^{18}$ The results of the study conducted at Cirebon also showed that there was a significant decrease in the level of anxiety in the intervention group after progressive relaxation therapy. ${ }^{9}$ Also in line with the research conducted at Yogyakarta also showed that there is an effect of providing progressive relaxation therapy to the anxiety level of preoperative patients. Other research in Magetan district shows that there is an influence of progressive muscle relaxation techniques on changes in anxiety levels. ${ }^{19}$

Some studies on progressive muscle relaxation of anxious patients get quite good results. Research on the effect of progressive relaxation techniques on anxiety levels in paranoid schizophrenic clients, states that the test results paired samples of anxiety levels in pretests and post-test obtained $\mathrm{t}$ value count 2.381 with a p-value of 0.029 . There was an influence significant progressive relaxation techniques against anxiety levels in paranoid schizophrenic clients. ${ }^{20}$

Both study subjects suffered from Schizophrenia. Initially experiencing a moderate level of anxiety, after relaxation therapy changed to a mild degree. There were significant differences in anxiety levels in both groups in post-implementation. The anxiety score of the first case study subjects decreased by $40.6 \%$ after being given progressive muscle relaxation, while the subjects of the second case study experienced a decrease of $46.7 \%$ after being given progressive muscle relaxation. These results are in line with the results of several studies that show that the administration of progressive relaxation techniques impact on the decrease in anxiety levels of schizophrenic patients. ${ }^{7}$

The results of this case study showed that progressive muscle relaxation therapy was able to lower anxiety levels in schizophrenic patients. It shows that progressive relaxation is effective to reduce muscle tension, anxiety and fatigue experienced by clients so that it will affect the client's mental status. These results are according to previous research that proves the benefits of progressive relaxation therapy are lowering muscle tension, reducing anxiety levels, stress-related problems such as hypertension, and insomnia. ${ }^{20}$

This case study showed that the study subjects experienced a decrease in anxiety levels from moderate to mild levels. Changes in anxiety levels after being given progressive muscle relaxation interventions become mild anxiety, in addition to the administration of antidepressant therapy also due to the influence of progressive muscle relaxation that further strengthens relaxation.

The findings of this case study corroborate all previous findings. Previous study in Taiwan demonstrated that progressive muscle relaxation training can effectively alleviate anxiety in patients with schizophrenia. ${ }^{21}$ Research at Surakarta Indonesia also concluded that progressive relaxation is effective to reduce muscle tension, anxiety and fatigue experienced by clients so that it will affect the mental status of the client. There was a significant difference in the anxiety level of respondents in both groups on the posttest. These results showed that the 
administration of progressive relaxation techniques had an impact on decreasing the anxiety levels of schizophrenic patients. So it is concluded there is a significant influence of progressive relaxation on the level of anxiety of schizophrenic clients. ${ }^{7}$ Efforts to prevent disease is to manage the stressors that come, the management is related to how the individual maintains his health. Health maintenance is the main brain function, the middle part of the brain when there is a stressor will stimulate the biochemical processes of the brain and relaxation response is the body's efforts to restore in a balanced state. Relaxation techniques can help restore mental, physical and emotional processes.

The results of the case study showed both case subjects experienced decreased levels of anxiety and reduced signs of anxiety after progressive muscle relaxation techniques were performed. This happens because the movement tightens and relaxes the muscles in a part of the body at a time to provide a feeling of physical relaxation in the muscle group performed in a row. Progressive muscle relaxation therapy helps reduce the tension presented in the muscles and this often generalizes to other areas of the body, including the mind. Learning to relax can reduce the damaging effects and symptoms of stress-induced diseases and improve a person's quality of life. ${ }^{8}$

This case study showed that progressive muscle relaxation was able to increase relax in patients who were shown decreased anxiety levels from the moderate category to the mild category followed by changes in vital signs in the form of decreased blood pressure, pulse and respiratory rate. Both respondents said they felt calm, relaxed and their worries diminished. Progressive muscle relaxation given to the study subjects stimulated the anterior pituitary to secrete encephalin and endorphins making the mood relax and happy. A pituitary gland also causes decreased secretion of adrenocorticotropic hormone (ACTH), which further controls the adrenal cortex to inhibit cortisol secretion. Decreased cortisol causes reduced stress and lowers anxiety. Previous study conclude that the efficacy of progtesive muscle relaxation extends to reduction in biologically expressed stress levels by decrease cortisol level.22 Progressive muscle relaxation training is a useful intervention as it is proven to reduce anxiety levels across a spectrum of psychiatric disorders. ${ }^{21}$

\section{CONCLUSION}

Progressive muscle relaxation therapy performed among schizophrenic patients for two days was able to reduce patient anxiety. There was a decrease in the anxiety scores of the two case study subjects. Recommendations for nurses to apply progressive muscle relaxation to reduce anxiety in schizophrenic patients

\section{ACKNOWLEDGMENT}

Special thanks to patients, nurses and doctors at two Hemodialysis Units in Semarang.

\section{CONFLICTS OF INTEREST}

Neither of the authors has any conflicts of interest that would bias the findings presented here.

\section{REFERENCES}

1. Maramis WF, Maramis AA. Catatan Ilmu Kedokteran Jiwa. II. Surabaya: Airlangga University Press; 2009.

2. Nasir A, Muhith A. Dasar-Dasar Keperawatan Jiwa: Pengantar dan Teori. Jakarta: Salemba Medika; 2011.

3. Stuart GW. Principle and practice of pscychiatric nursing. 10th ed. St Louis: Elsevier; 2013.

4. WHO. World health statistics 2019: monitoring health for the SDGs, sustainable development goals. 2019.

5. Ulfa NM. Efektivitas Terapi Relaksasi Dzikir dalam Menurunkan Kecemasan Pasien Skizofrenia di UPT (Unit Pelaksana Teknis) Rehabilitasi Sosial Bina Laras Kediri. UIN 
Tulungagung; 2019.

6. Wahyuningsih, Sutanta, Afifah VA. Pengaruh Teknik Relaksasi Nafas Dalam Terhadap Tingkat Kecemasan Pasien Pre Operasi Fraktur Femur. Media Ilmu Kesehat. 2019;3:230-6.

7. Ari PLD, Pratiwi A. Pengaruh relaksasi progresif terhadap tingkat kecemasan pada pasien skizofrenia di rumah sakit jiwa daerah Surakarta. 2010;

8. Lindquist R, Tracy MF, Snyder M. Complementary and Alternative Therapies in Nursing. 8th ed. New York: Springer International Publishing; 2018.

9. Hidayat E. Pengaruh Terapi Relaksasi Progresif terhadap Penurunan Tingkat Kecemasan dalam Menghadapi Uji Kompetensi Mahasiswa Tingkat III Akper Muhammadiyah Cirebon. J Keperawatan Soedirman. 2017;12:93-101.

10. Nursalam. Konsep dan penerapan metode penelitian ilmu keperawatan. Jakarta: Salemba Medika; 2013.

11. NANDA. Nursing Diagnoses Definitions \& Classification 2018-2020. Heather T. Herdman SK, editor. New York: Thieme; 2018.

12. Pokja SIKI PPNI. Standar intervensi keperawatan Indonesia definsi \& tIndakan keperawatan. I. Jakarta: PPNI; 2018.

13. PPNI. Standar luaran keperawatan Indonesia. Jakarta: PPNI; 2019.

14. Vellyana D, Lestari A, Rahmawati A. FaktorFaktor yang Berhubungan dengan Tingkat Kecemasan pada Pasien Preoperative di RS Mitra Husada Pringsewu. J Kesehat. 2017;8:108-13.

15. McLean CP, Asnaani A, Litz BT, Hofmann SG.
Gender differences in anxiety disorders: Prevalence, course of illness, comorbidity and burden of illness. J Psychiatr Res. 2011;45:1027-35.

16. Asnaniar WOS, Agustini T. Progressive Muscle Relaxation Reduces Depression in Elderly. Wind Heal. 2018;1:1-5.

17. Fhadilah NC, Adi WS, Shobirun S. Pengaruh Terapi Relaksasi Otot Progresif Terhadap Pasien Resiko Perilaku Kekerasan di RSJD dr Amino Gondohutomo Provinsi Jawa Tengah. J Forum Kesehat. 2017;7:83-9.

18. Kustanti E, Widodo A. Pengaruh teknik relaksasi terhadap perubahan status mental klien skizofrenia di rumah sakit jiwa daerah surakarta. J Ber Ilmu Keperawatan. 2008;1:131-6.

19. Suharno S, Septiyani G. Pengaruh Progresif Terhadap Tingkat Kecemasan pada Pasien Skizofrenia di Panti Gramesia Kabupaten Cirebon. J Kampus STIKES YPIB Majalengka. 2019;7:1-14.

20. Anindita B, Ambarwati WN, Listyorini D. Pengaruh teknik relaksasi progresif terhadap tingkat kecemasan pada klien skizofrenia paranoid di RSJD Surakarta. Universitas Muhammadiyah Surakarta; 2012.

21. Chen W, Chu H, Lu R, Chou Y, Chen C, Chang Y, et al. Efficacy of progressive muscle relaxation training in reducing anxiety in patients with acute schizophrenia. J Clin Nurs. 2009;18:218796.

22. Chellew K, Evans P, Fornes-Vives J, Pérez G, Garcia-Banda G. The effect of progressive muscle relaxation on daily cortisol secretion. Stress. 2015;18:538-44. 